\title{
Stage IVB Vaginal Cancer AJCC v6 and v7
}

National Cancer Institute

\section{Source}

National Cancer Institute. Stage IVB Vaginal Cancer AJCC v6 and v7. NCI Thesaurus. Code C9355.

Stage IVB includes: Any T, Any N, M1. M1: Distant metastasis. (AJCC 6th and 7th eds.) 